التعرف على تأثير نمو نباتات مختلفة على المجتمع الميكروبى فى كل من التربة و المحيط

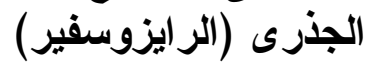

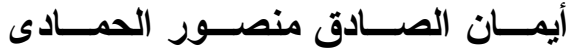

قسم الثربة و المياه، كلية الزر اعة ، جامعة طر ابلس، ليييا

emanbensaeed@gmail.com



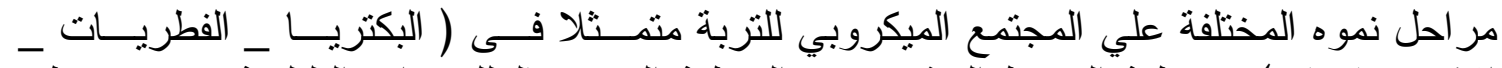

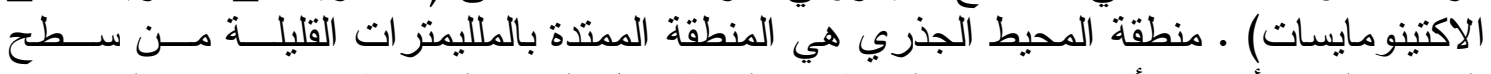



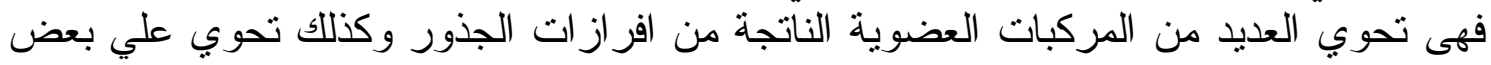







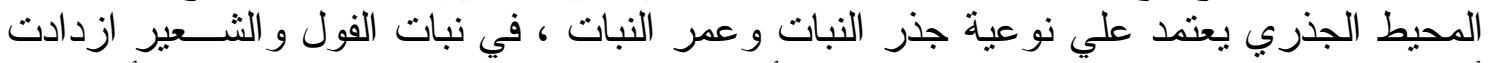

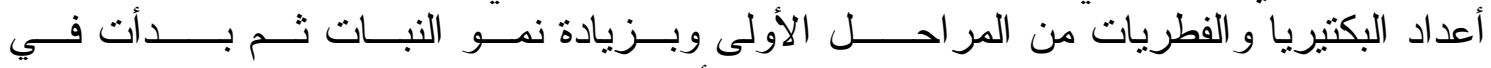

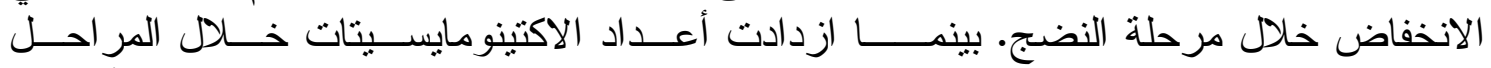

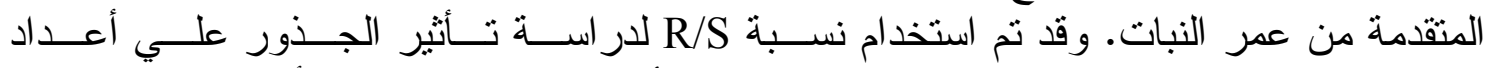



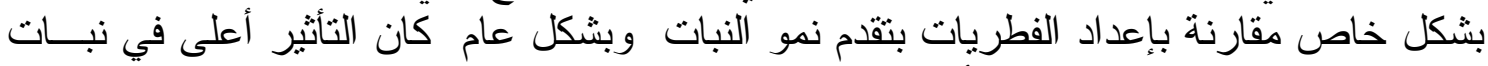

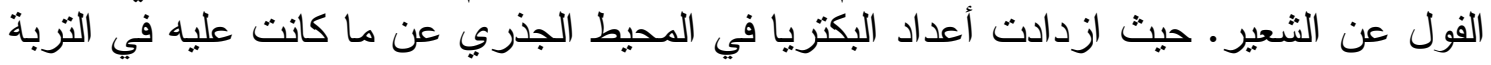

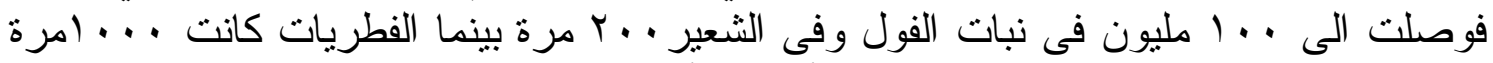

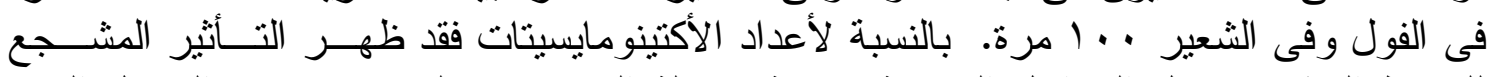



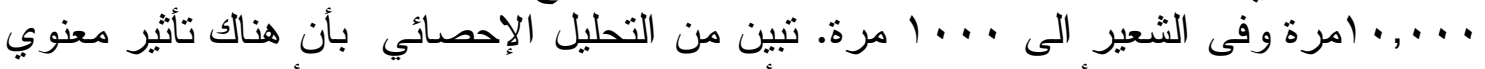

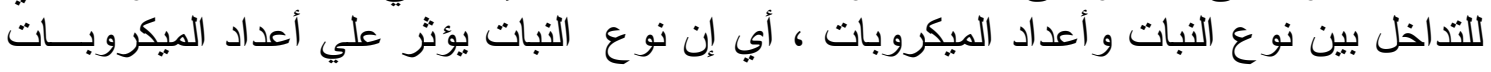

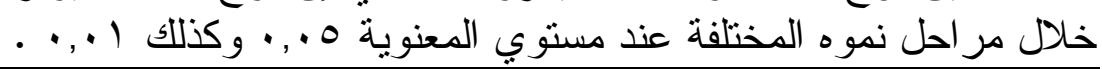

Received on: 13/12/2014

Accepted for publication on: 18/2/2015

Referees: Prof. Salah M. Mohamed

Prof. Ahmed M. Abd elwahab 


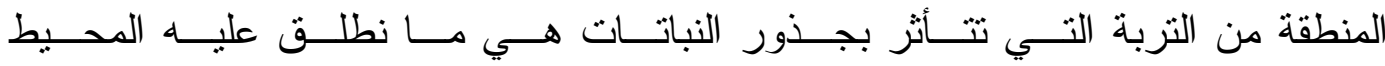
الجذري Rhizosphere كما إن هذه المنطــقة من التزبة هي التي تتغير فيها إعداد الميكروبــات



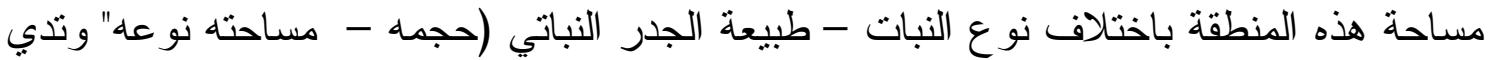

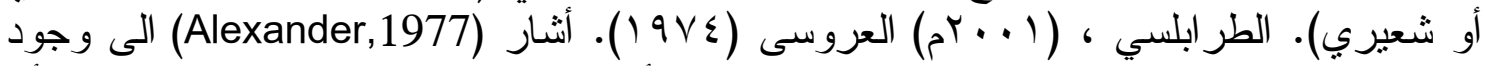
مجتمع كثيف من الميكروبات يحيط بالجذور ، و على أسطح انسجتها وشعير اتها الخارجية ، و أن

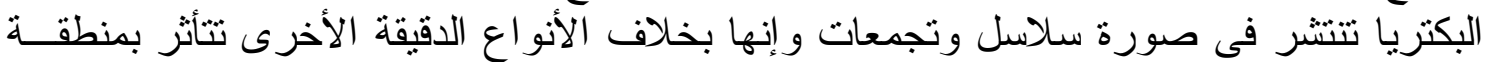

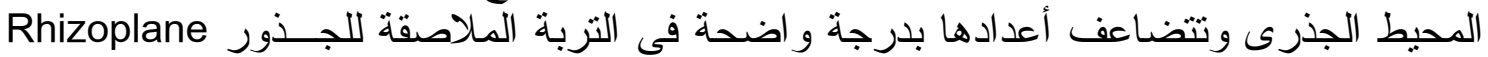



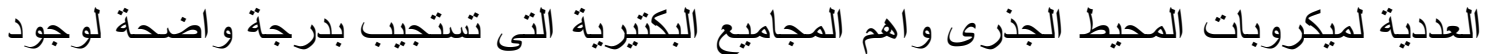

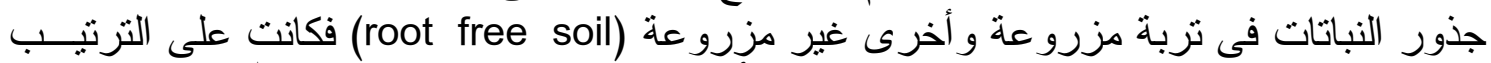

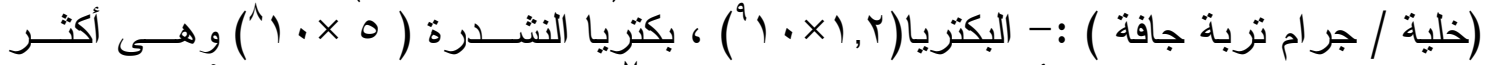

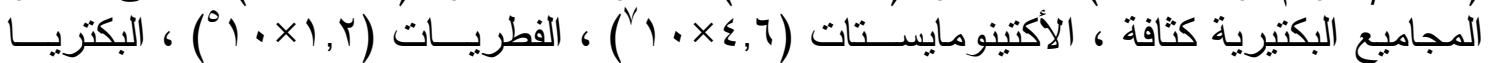

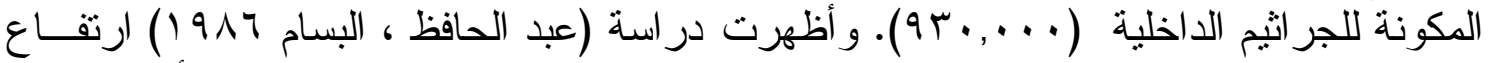
الاعداد الكلية للبكتريا في المحيط الجذرى لتربة قاعدية واختلافات كبيرة من نبات لأخر علاوة على التذبذبات الموسمية ، كما توصلت الى ان للجذور تأثنير ايجابي على المجمو عة الميكروبية

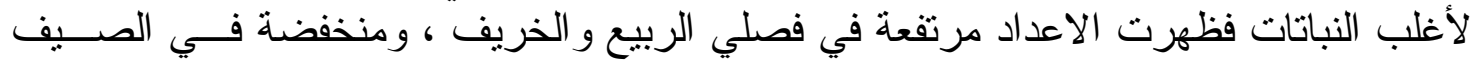

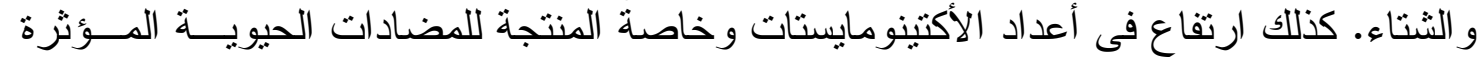

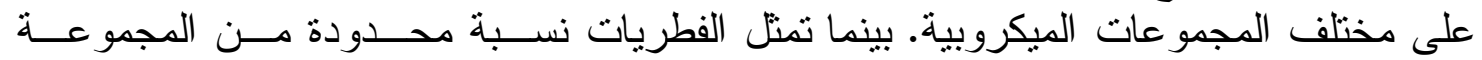

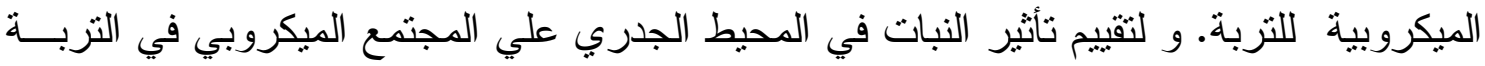

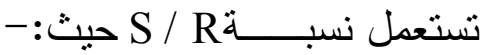
R: هي إعداد الميكروبات النامية في المنطقة المحيطة بالجذور



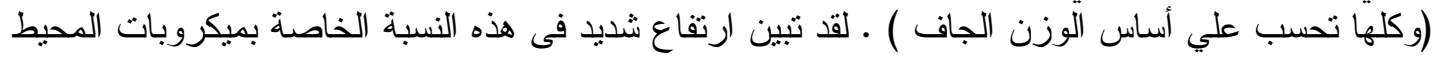



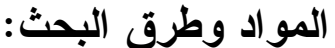

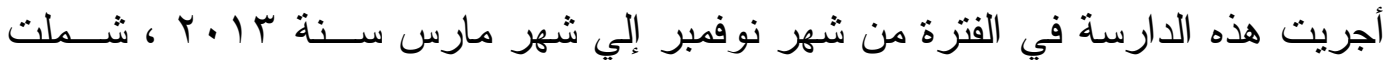

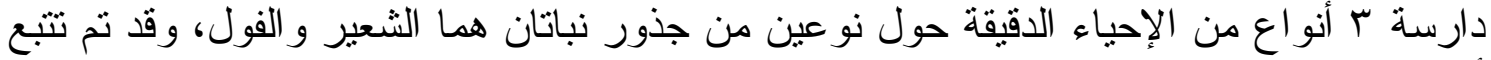



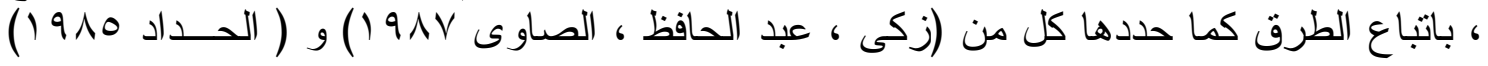



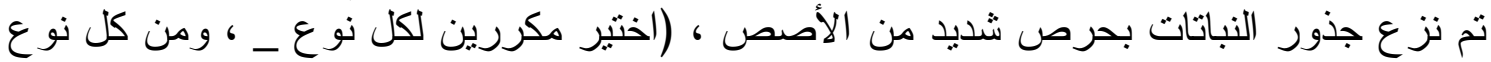

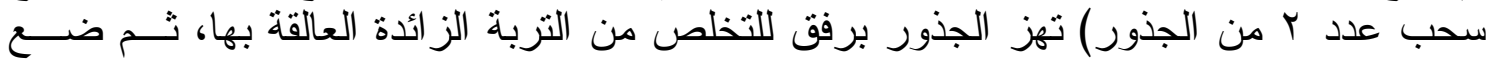

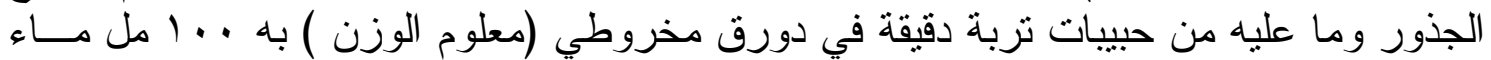


إلي أطباق بتري معقمة. لتقدير أعداد الميكروبات (بكتيريا - فطريات - اكتينومايسيتات) كما هو



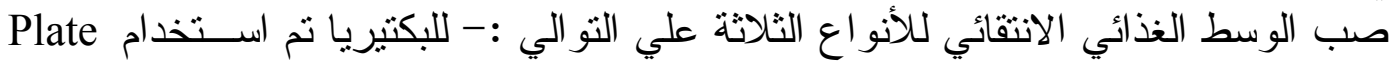

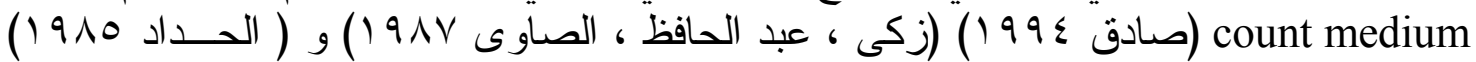

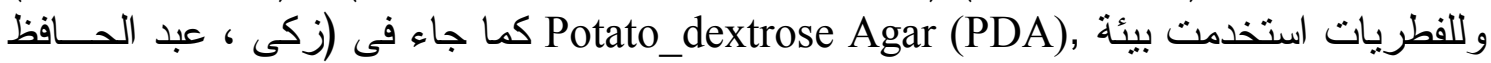

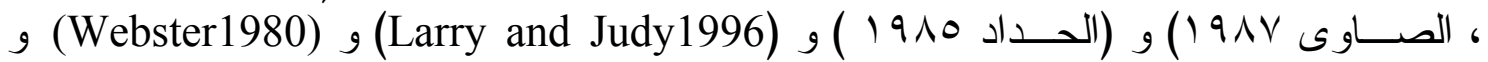






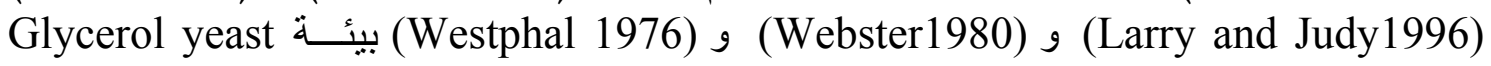
extract Agar تقدير وزن التربة حول الجذور: - يز ال الجذر من الدورق المخروطي ويغسل جيدأ بالماء المقطر ويضاف مـــاء الغســيل إلــي

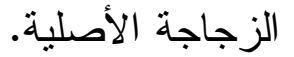

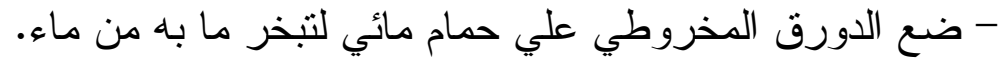

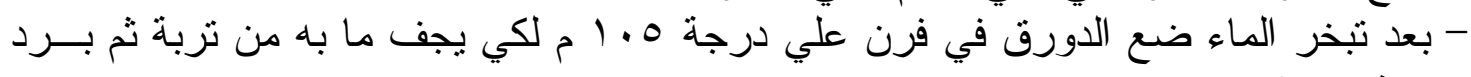



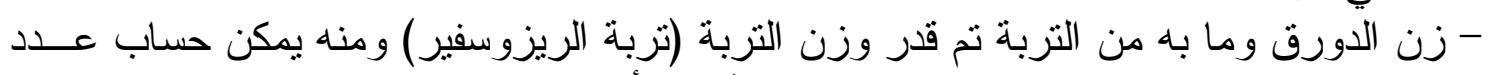

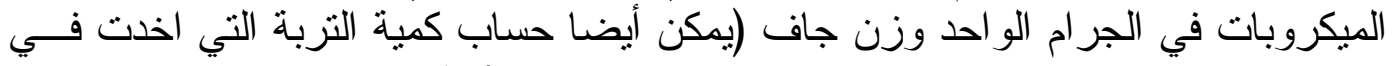

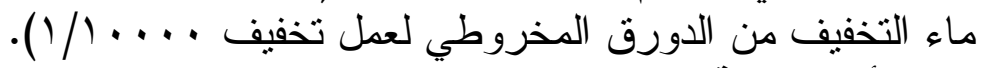



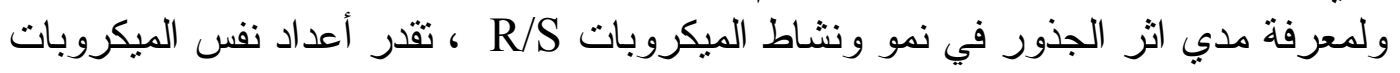



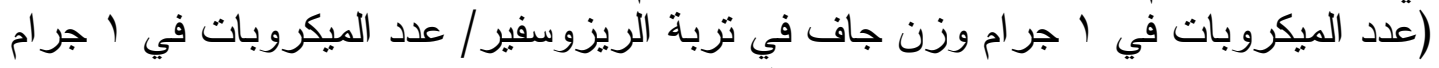

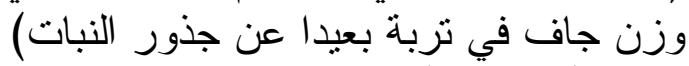
Rossi_Cholodny ) الاراسة الوصفية للميكروبات بالر ايزوسفير بطريقة الثريحة المدفونة)

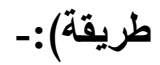

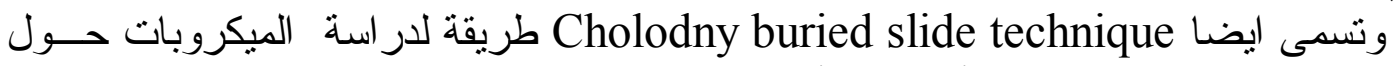

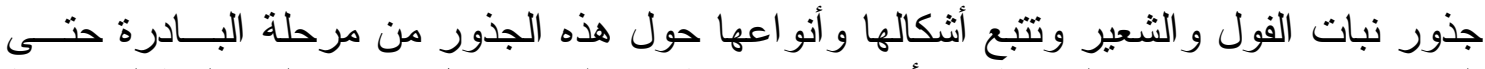

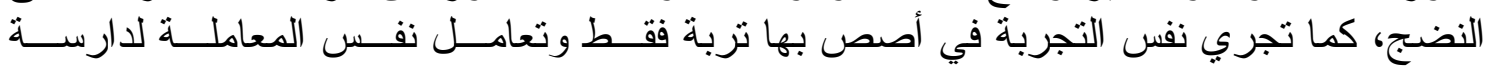

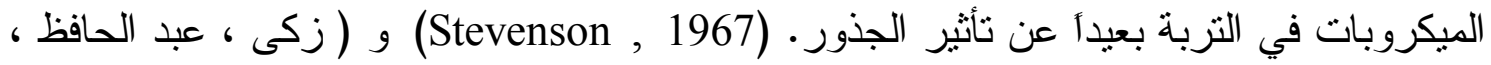

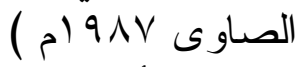

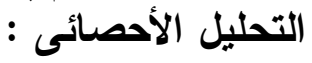



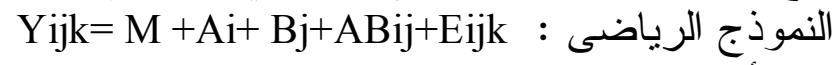

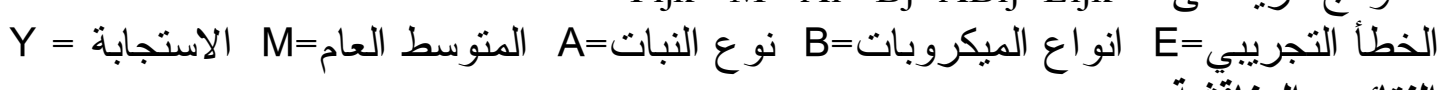

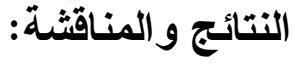

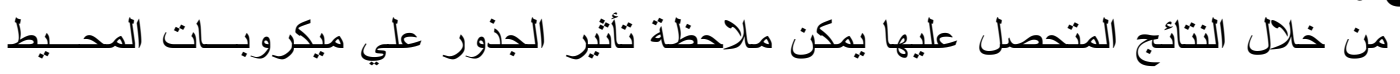

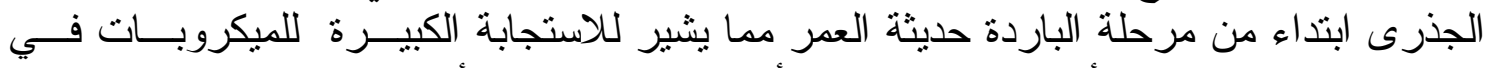

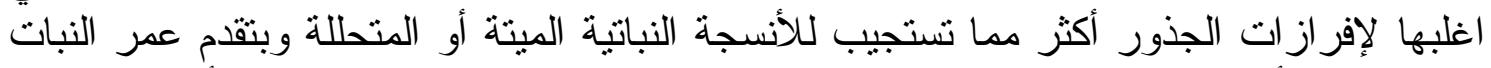

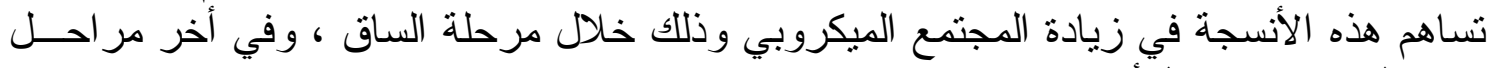

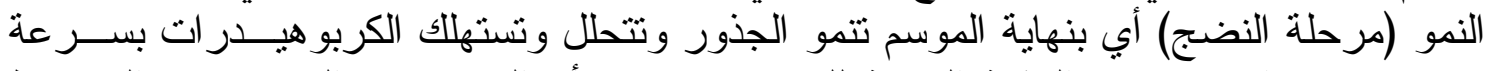





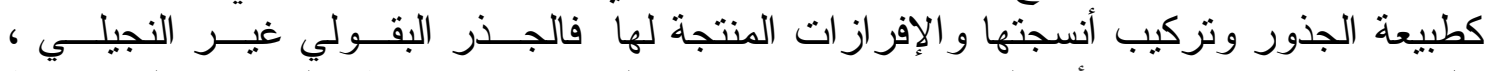

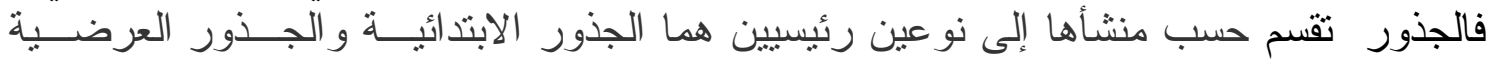

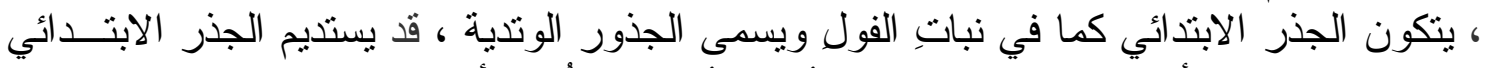

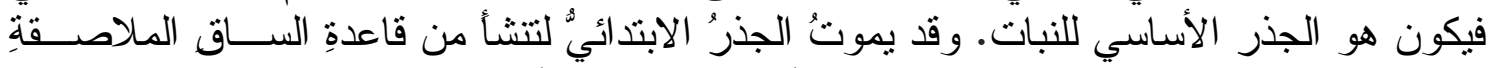

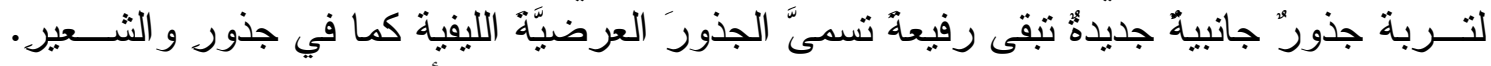

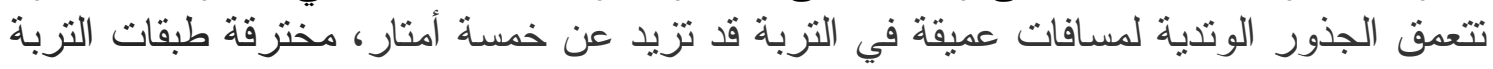


المختلفة لامتصاص العناصر الغذائية من أعماق التزبة. رغم أن المساحة التى يشغلها هذا الجذر الترا

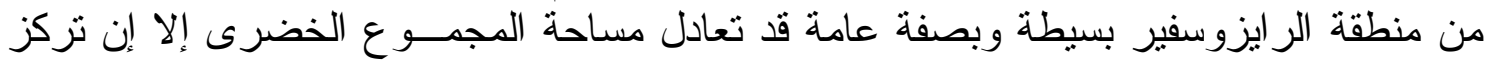

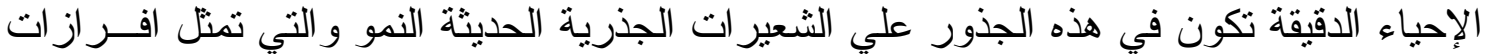

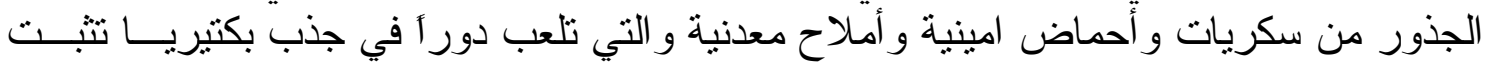
النتروجين الجوي التي تقوم بتوفير عنصر النتروجين و امداداه للنبات بواسطة العقد الجذرية فيما

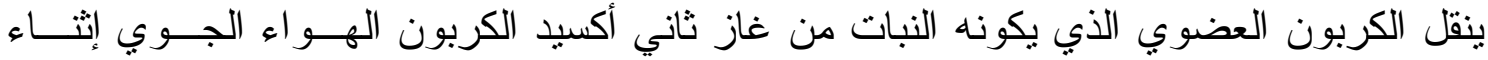



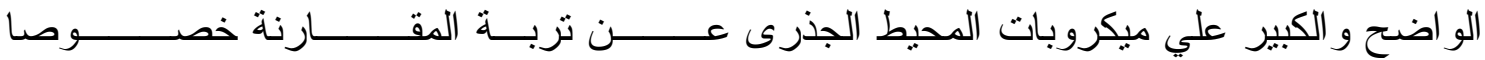



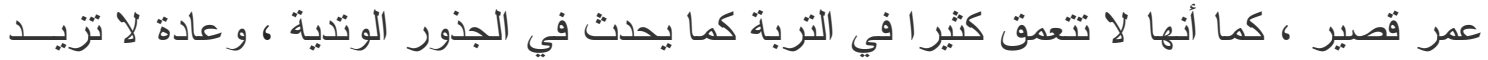

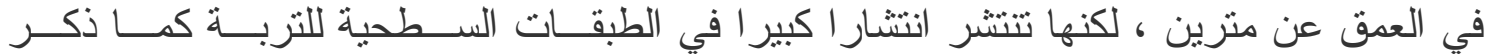

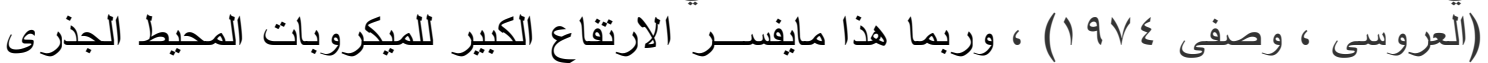
لنبـات الفول عن الثعير إضافة الى أن سمك الجذر الوتدى هو أكثر من الليفى ووجود الجذور

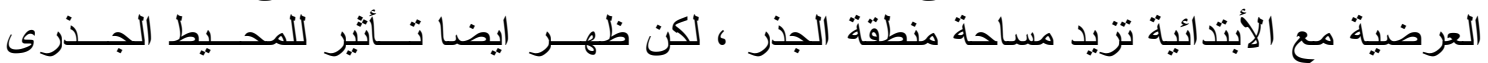

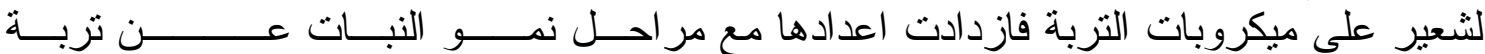

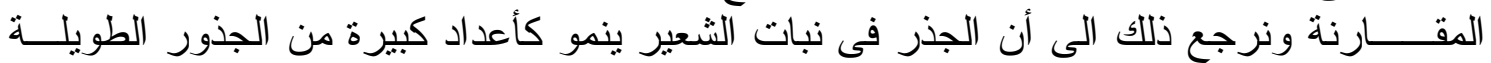
و الرفيعة بدل جذر رئيسي واحد فالمساحة السطحية لهذه الجذور كبيرة ، كذلك وزن الجذر يشكل

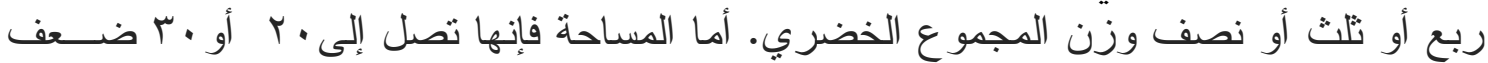



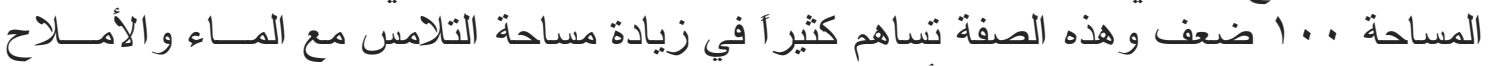

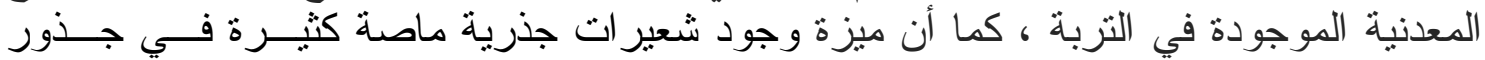

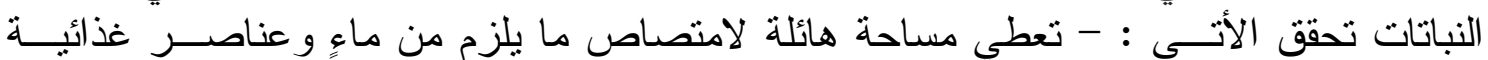
بكمية كبيرة.


الاستفادة من أكبر كمية من الماء و العناصر الغذائية المتو افرة في التزبة. وبذلك منطقة المحــيط

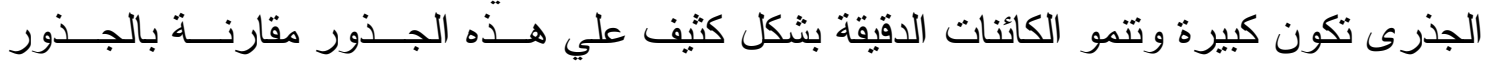



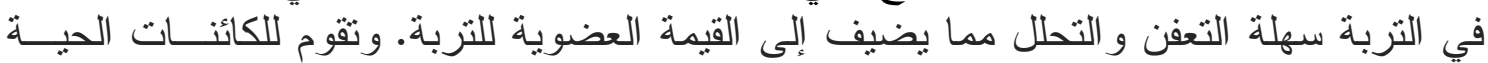

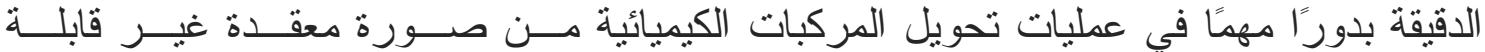

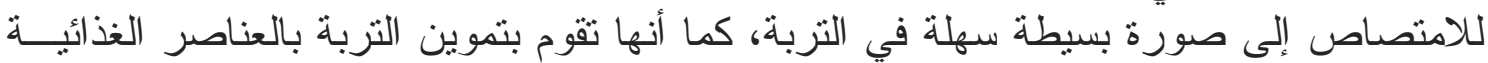
Teresa, الازمة لنمو النباتات وسريعة الامتصاص من الجذور في التزبة. و هذا مابينه كل من



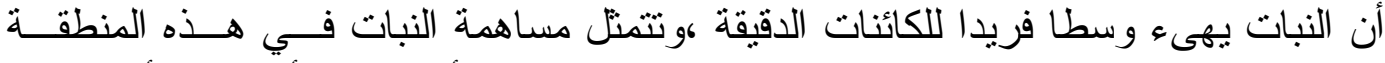

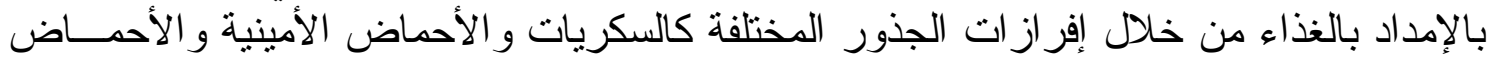

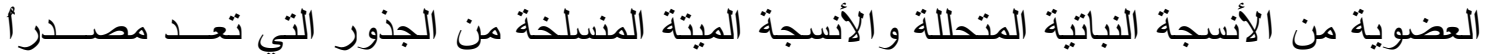

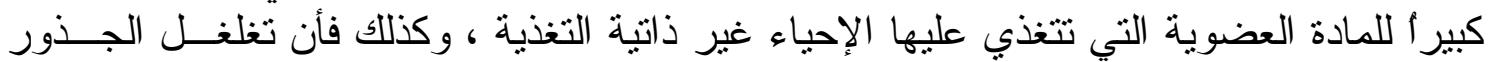

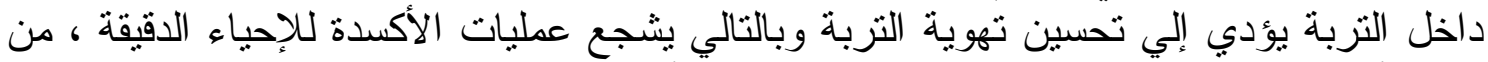

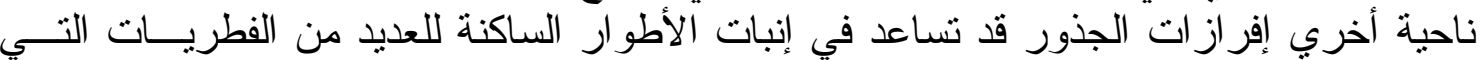

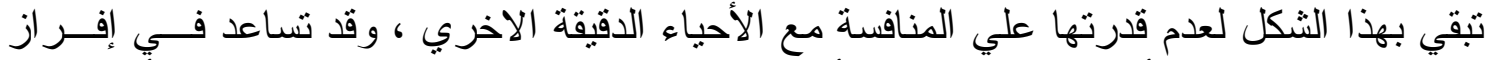

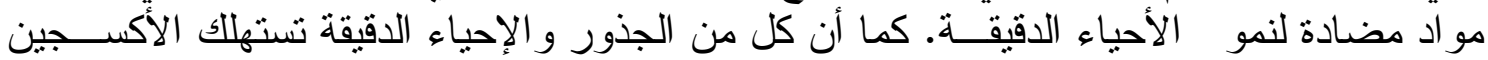

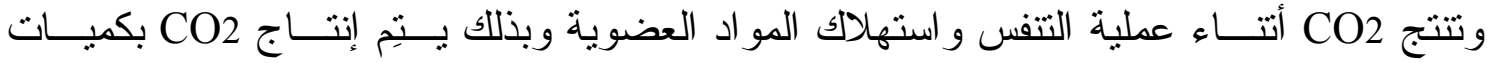
كبيرة في منطقة المحيط الجدري ويتكون حامض الكربونيك الذي يؤثز بشكل مباشر على دئ درجة

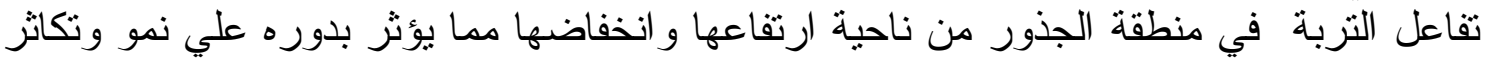


الميكروبات ويساعد في ذوبان بعض المو اد المعدنية غير الذائبة كمركبات الفوسفور و البوتاسيوم

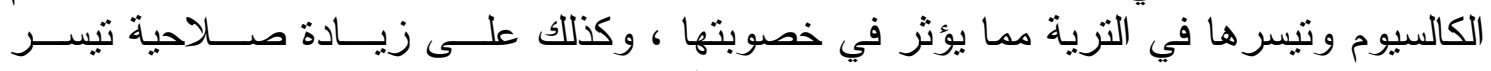

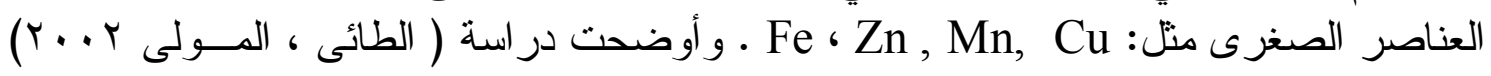

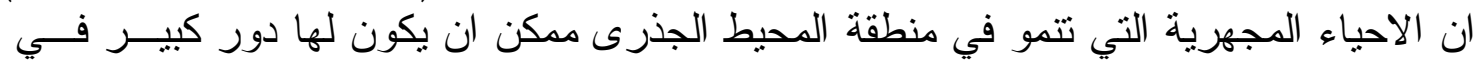

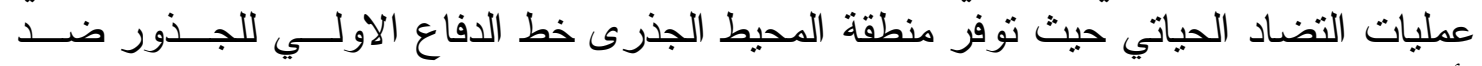

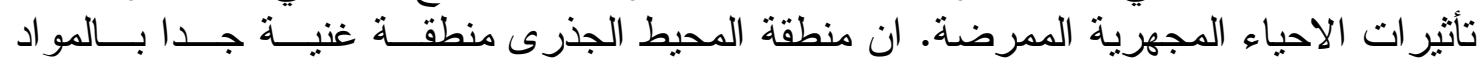
العضوية وتكون مفعمة بالنشاط البكتيري نظر الوجود الاهير الجذور النباتية التي بدور ها تقوم بعمليات

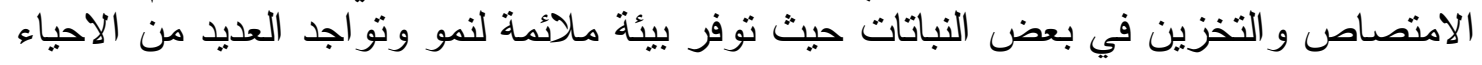

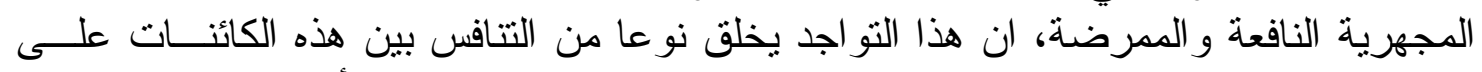

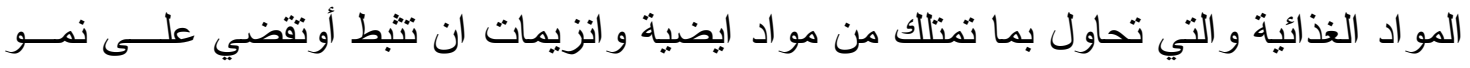

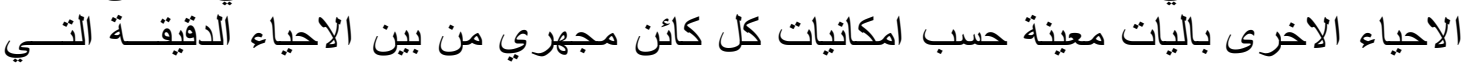

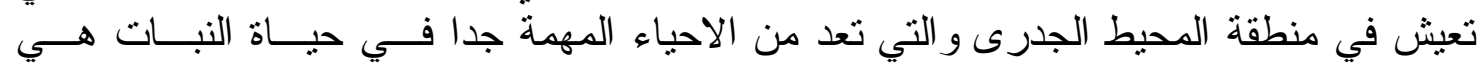





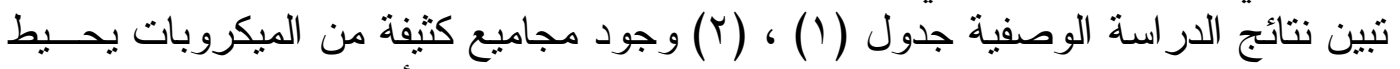

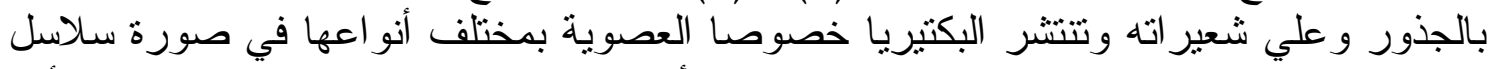

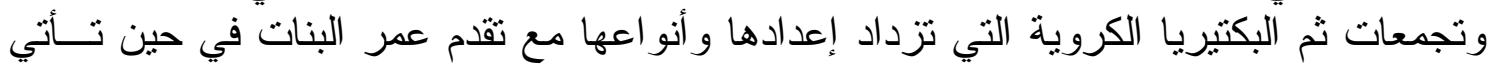

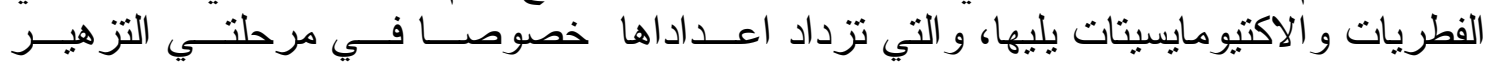

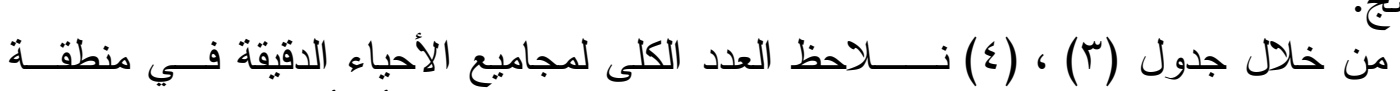
و النضجن



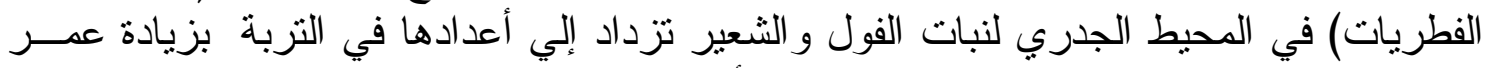

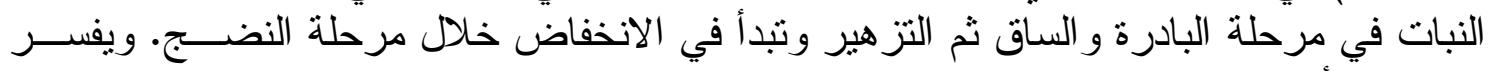
ذللك على أن الافراز ات الجذرية تكون قليلة وصغيرة وسهلة التركيب و وعندما يكبر النبات يزداد النياد

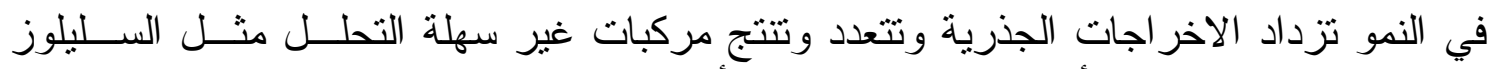



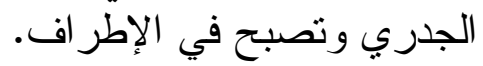







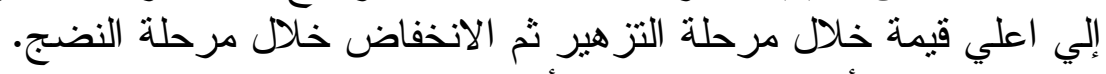





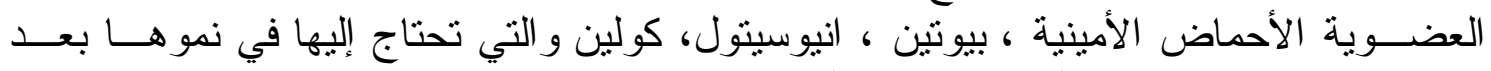



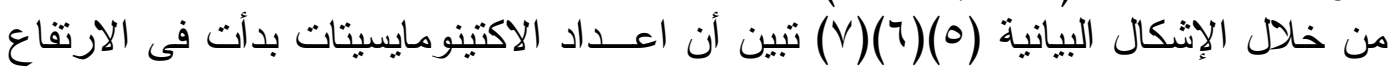



$$
\begin{aligned}
& \text { بينت نتائج فى جدول (0) ، (7) أعداد الإحياء الدقيقة في المحيط الجذري إلي أعدادها في } \\
& \text { التزبة باستخدام }
\end{aligned}
$$

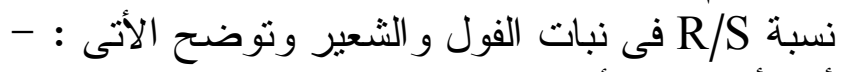





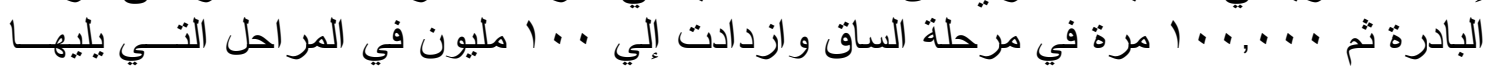


بينما نبات الثعير كان اكبر تأثثر خلال مرحلة التزهير مقارنة بالمر احل الاخري. حيث وصـل

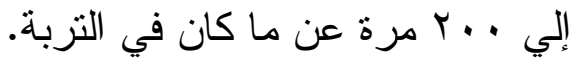

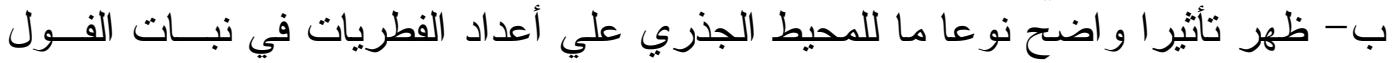







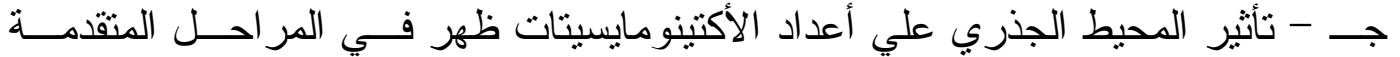

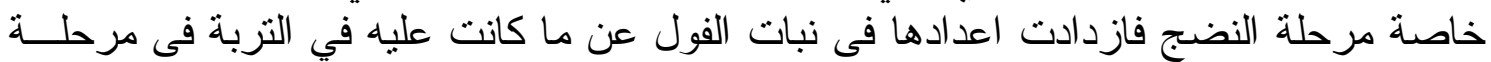

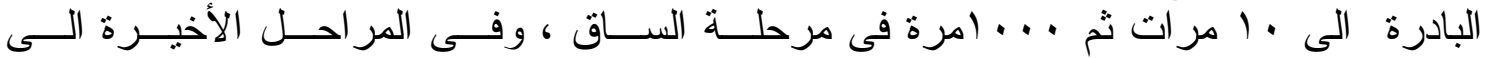



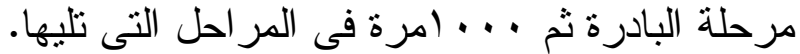





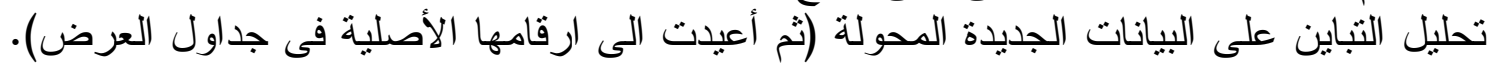



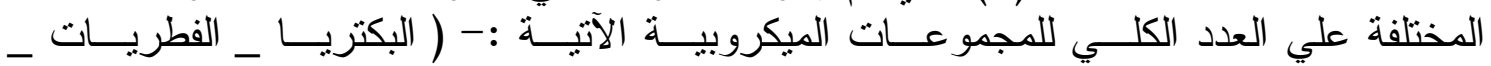

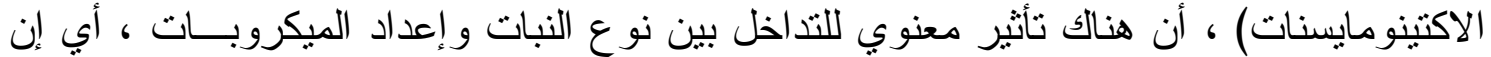

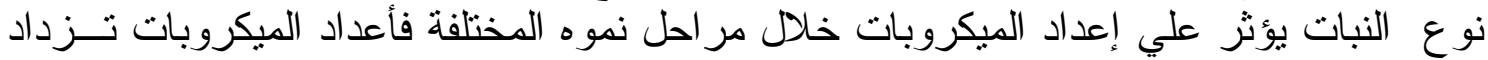





\section{جدول (1): الار اسة الوصفية لميكروبات التربة حول جذور نبات الفول خــلا مراحسل نمــو} المختلفة

\begin{tabular}{|c|c|c|c|c|}
\hline مرحلة النضج & مرحلة التزهير & مرحلة الساق & مرحلة البادرة & الإحياء \\
\hline 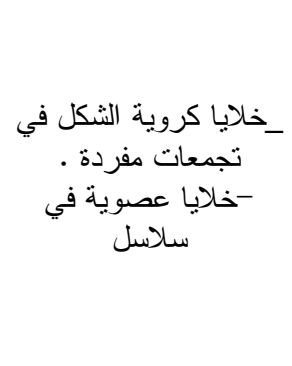 & 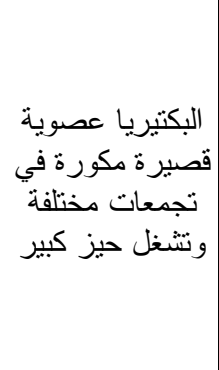 & 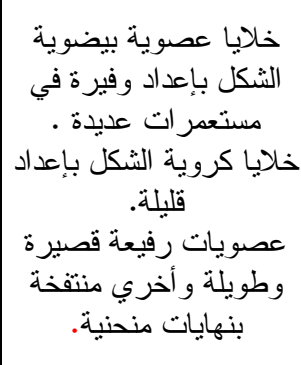 & 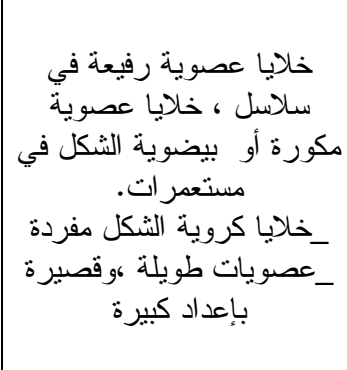 & البكتيريا \\
\hline  & 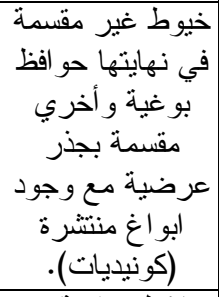 & 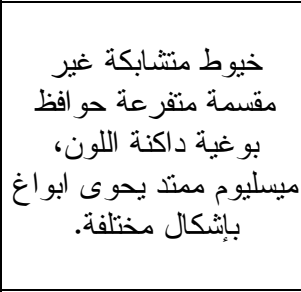 &  & الفطريات \\
\hline خيوط رفكل كبير منشرة & 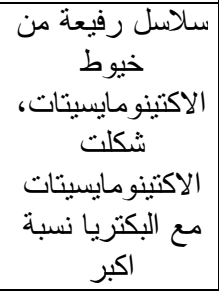 & خيوطة متفرة رفيرة بإعداد غير & مقيمة ، خيوط قصئبرة رفيعة غيرة & اكتينومايسيتات \\
\hline
\end{tabular}


جدول (ץ) :الار اسة الوصفية لميكروبات التربة حول جذور نبات الشعير خلال مراحـل النمــو المختلفة

\begin{tabular}{|c|c|c|c|c|}
\hline مرحلة النضج & مرحلة الترهيز & مرحلة الساق & مرحلة البادرة & مراحل النمو \\
\hline 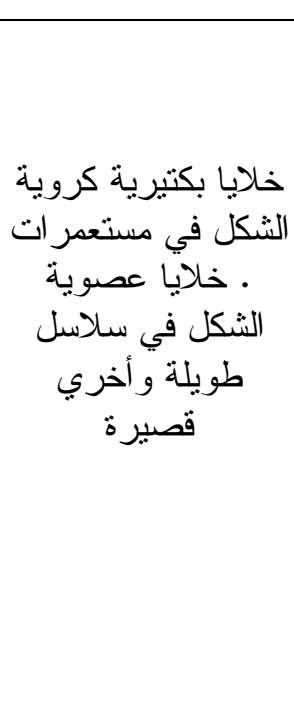 & خلايا كريلة في مسيرة ،ورية، أخرية الثعرية &  & 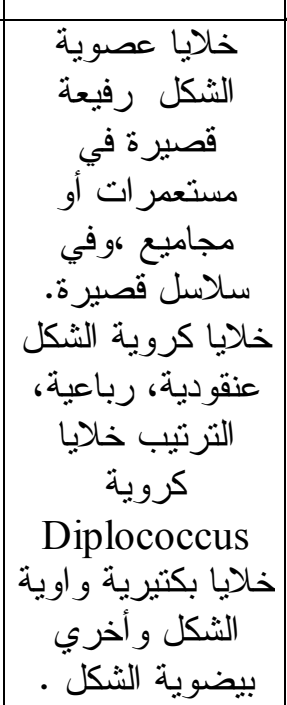 & البكتيريا \\
\hline 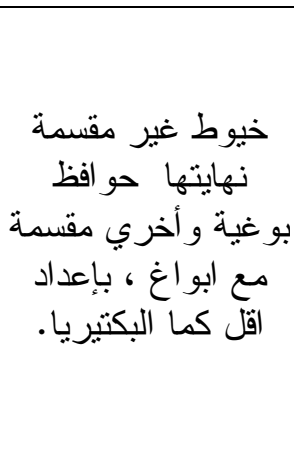 & 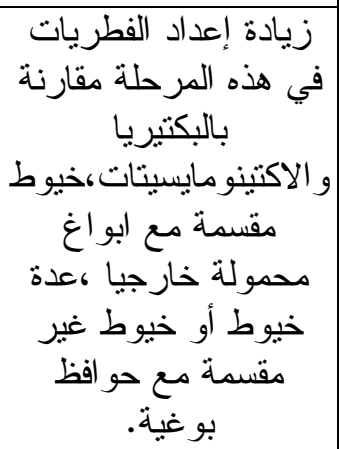 & 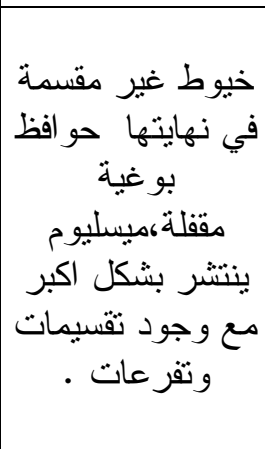 & 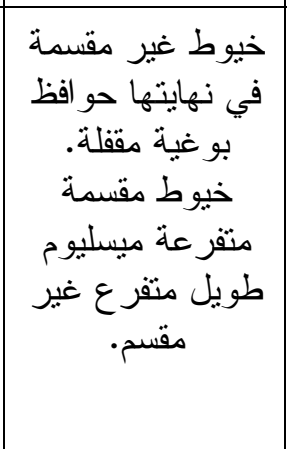 & الفطريات \\
\hline الاكتينوة خيوطيسيتات رفيعة من مقير & و خيوط رفيعة جدا من & 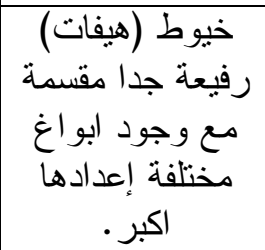 &  & اكتينومايسيتات \\
\hline
\end{tabular}


جدول (ب): العدد الكلى لمجاميع الأحياء الاقيقة في منطقة الر ايزوسفير لتبــات الفــول خــلال

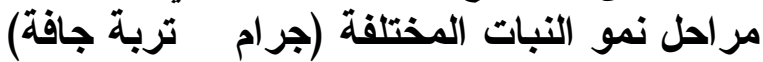

\begin{tabular}{|c|c|c|c|c|}
\hline مرحلة النضج & مرحلة التزهير & مرحلة الساق & مرحلة البادرة & مر احل النمو \\
\hline $2.193 \times 10^{16}$ & $2.547 \times 10^{16}$ & $1.793 \times 10^{13}$ & $4.549 \times 10^{12}$ & I. البكتريا \\
\hline $2.671 \times 10^{10}$ & $4.283 \times 10^{10}$ & $1.493 \times 10^{10}$ & $4.277 \times 10^{8}$ & 2. الفطريات \\
\hline $3.426 \times 10^{11}$ & $2.705 \times 10^{11}$ & $1.406 \times 10^{10}$ & $3.834 \times 10^{8}$ & 3. اكتينومايستيات \\
\hline
\end{tabular}

جدول(ء): العدد الكلى لمجاميع الأحياء الدقيقة في منطقة الرايزوسفير لنبات الشــير خــلال



\begin{tabular}{|c|c|c|c|c|}
\hline مرحلة النضج & مرحلة التزهير & مرحلة الساق & مرحلة البادرة & مر احل النمو \\
\hline $1.331 \times 10^{10}$ & $3.292 \times 10^{10}$ & $1.598 \times 10^{10}$ & $3.749 \times 10^{8}$ & II. البكتريا \\
\hline $2.959 \times 10^{9}$ & $5.809 \times 10^{9}$ & $9.502 \times 10^{8}$ & $8.306 \times 10^{8}$ & 2. الفطريات \\
\hline $5.3 \times 10^{10}$ & $3.513 \times 10^{10}$ & $2.612 \times 10^{10}$ & $7.448 \times 10^{7}$ & 3. اكتينومايستيات \\
\hline
\end{tabular}

جـدول (0): أعداد الإحياء الدقيقة في المحيط الجذري إلي إعدادها في التربــة باســتخدام نسبة R/S في نبات الفول



جدول (†): أعداد الإحياء الاقيقة في المحيط الجذري إلي إعدادها في التربة باستخدام نسـبة R/S 


\begin{tabular}{|c|c|c|c|c|}
\hline مرحلة النضج & مرحلة التزهير & مرحلة الساق & مرحلة البادرة & مر احل النمو \\
\hline 81 & 200 & 97 & 2.3 & I .البكتريا \\
\hline 62 & 122 & 17.4 & 2.0 & 2 \\
\hline 462 & 540 & 402 & 1.1 & 3 . (كتينومايستيات \\
\hline
\end{tabular}

جدول (V) : أعداد الأحياء الدقيقة في تربة المقارنة ( تربة بعيدة عن الجذور):

\begin{tabular}{|c|c|c|c|}
\hline اكتينومايستيات & الفطريات & البكتريا & مجاميع الإحياء الاقيقة \\
\hline $6.5 \times 10^{7}$ & $4.775 \times 10^{7}$ & $1.64 \times 10^{8}$ & العدد الكلي (جرام تربة جافة) \\
\hline
\end{tabular}

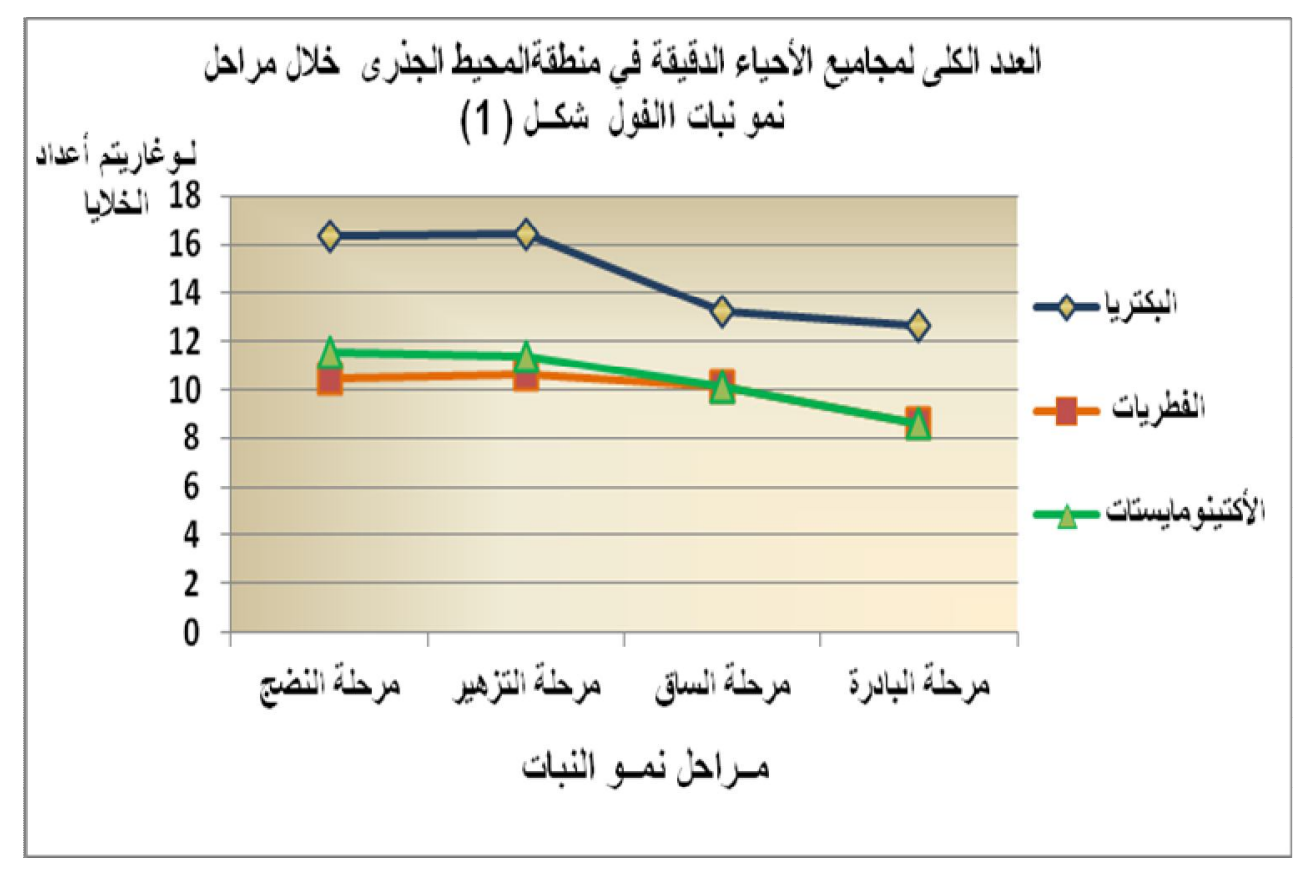



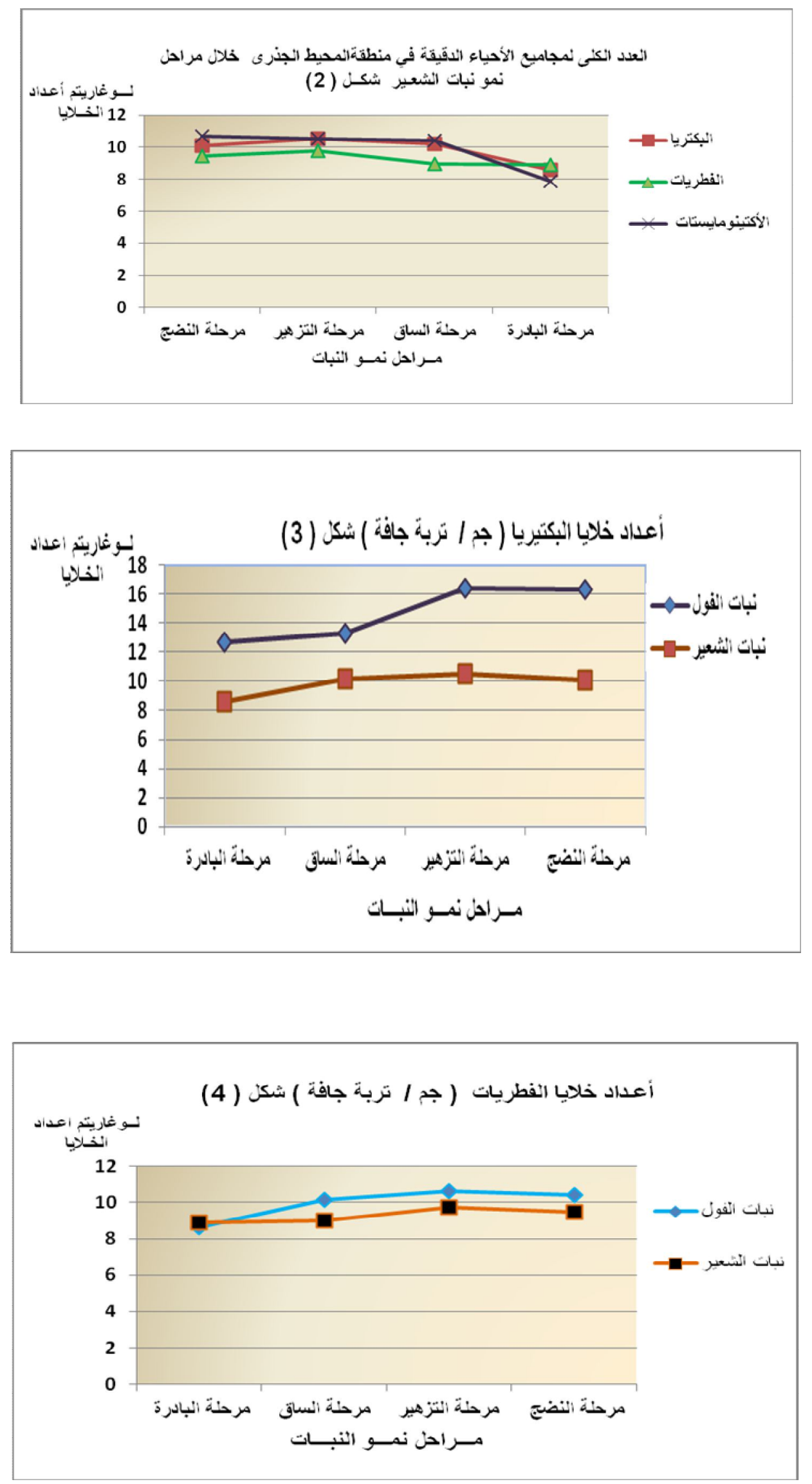


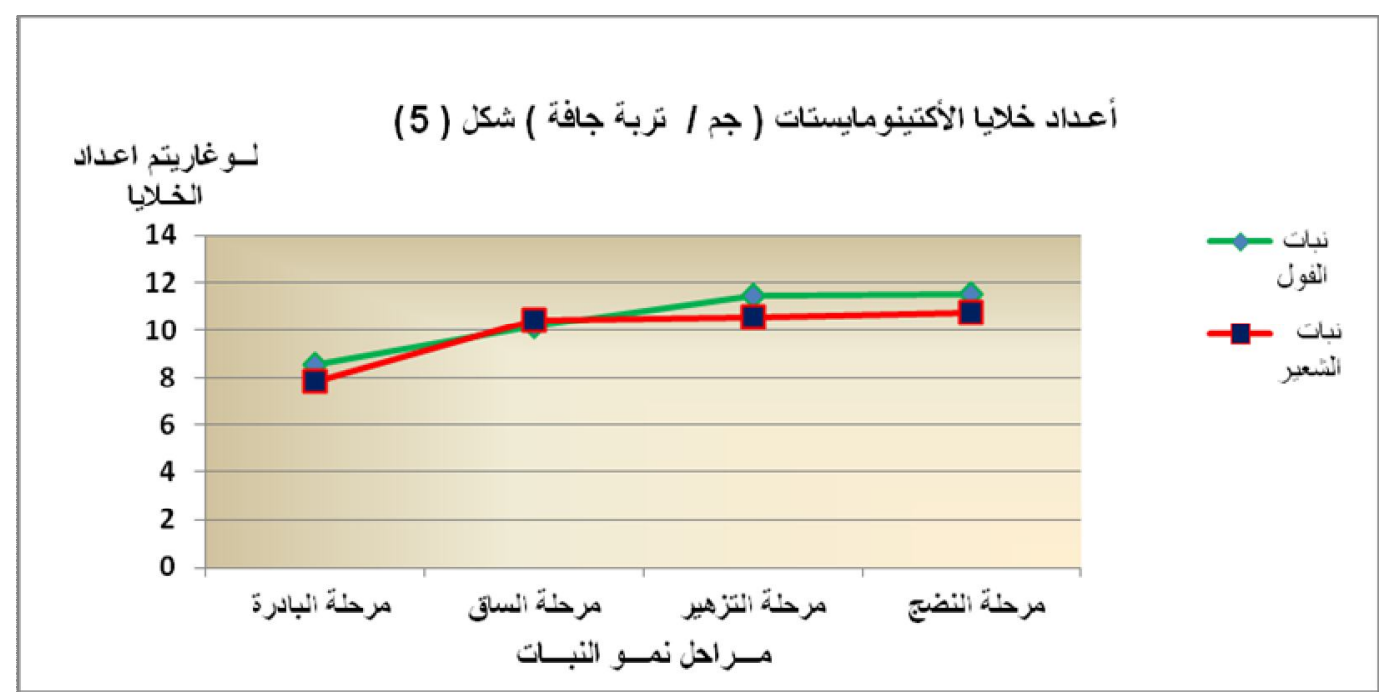

جدول (^) : جدول تحليل التباين ANOVA

\begin{tabular}{|c|c|c|c|c|c|c|}
\hline \multirow{2}{*}{ (مصدر الاختلافات) } & \multirow{2}{*}{$\begin{array}{c}\text { (لدرية) } \\
\text { d.f }\end{array}$} & \multirow{2}{*}{$\begin{array}{c}\text { (مجمو الافات } \\
\text { المربعة) } \\
\text { SSQ }\end{array}$} & \multirow{2}{*}{ الانحر (فتاث } & \multirow{2}{*}{ F المحسوبة } & \multicolumn{2}{|c|}{ F الجدولية } \\
\hline & & & & & $\cdot, \cdot 0$ & $\cdot, \cdot 1$ \\
\hline Total الكلية & r & 11,01 & - & - & & \\
\hline المعاملاتTreatments & 0 & $\varepsilon \wedge, \Gamma \backslash \wedge$ & אודר & $5.240 * *$ & 2.77 & 4.55 \\
\hline A & r & $1 \cdot, \wedge \vee 1$ & & 2.948 & 3.55 & 6.01 \\
\hline B & 1 & . & דיד & 0.50 & 4.41 & 8.29 \\
\hline $\mathrm{AB}$ & r & 47,011 & 11, Y०1 & $9.899 * *$ & 3.55 & 6.01 \\
\hline errorأخطأ & 11 & & $1, \wedge \leq \varepsilon$ & & & \\
\hline
\end{tabular}

F** المحسوبة اكبر من F الجدولية ، لذا فالفروق عالية المعنوية . 




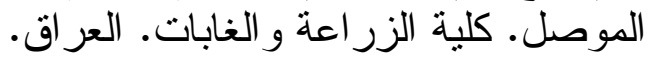



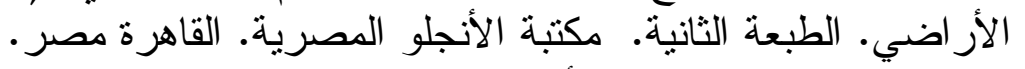

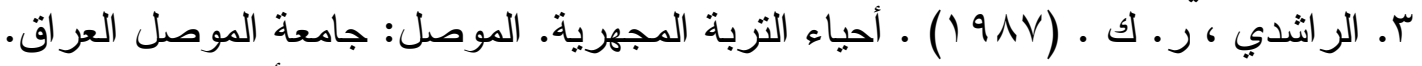

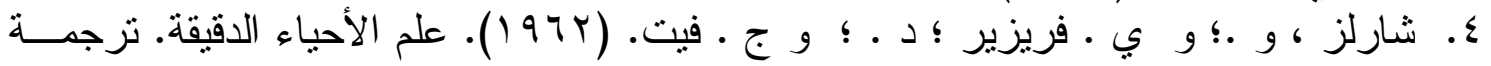

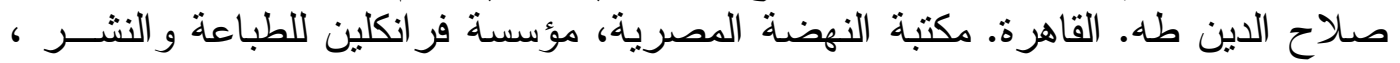

$$
\text { نيو يورك. }
$$

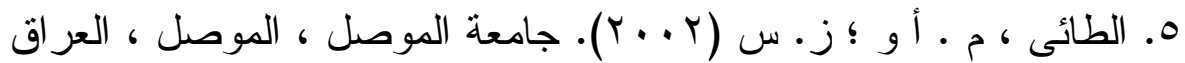





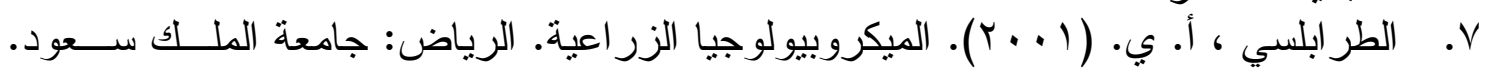
المملكة العربية السعودية. المران.

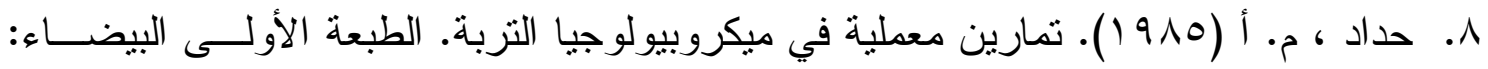
جامعة عمر المختار .ليبيا

9 . .صادق. ع • • ( 99 (1). التجارب العملية في علم الأحياء الدقيقة. الطبعة الأولى. الرياض. عمادة شؤون المكتبات ، جامعة الملك سعود. المملكة العربية السعودية.

10. Alexander, M. (1977) Introduction to soil Microbiology. NewYork ; John Wiley and Sons . Inc. U.S.A.

11. MCkane Larry and Kandel Judy (1996). Microbiology: Essentials and applications. 2 ed USA: McGraw -Hill, Inc.

12. Rovira,A.D.1965.Plant root exudales and their in fluence upon soil microorganisms.

Ecology of soil_Borne plant pathogens.eds .Baker, K .F and Synder,W.C.

13. Stevenson, G. (1967). The Biology of Fungi, Bacteria and Viruses. London: Edward Arnold ( Publishers) Ltd .

14. Teresa, A. and Gerald. A. (1996): Biology, Life on Earth (Fourth Edition). Prentice Hall Upper Saddle River, NewJersey 07458 .

15. Webster, J. (1980) . Introduction to Fungi . London, NewYork: Cambridge.

16. Westphal, A. (1976). Protozoa . Blackie and Sons Ltd. 


\title{
Identification the Impact of Growth of Different Plants on the Microbial Community in Both Soil and Rhizosphere
}

\author{
Eeman A. Al-HAMMADI
}

Tripoli University, Faculty of Agriculture, Tripoli, Libya

\section{Abstract:}

This experiment was conducted to study the importance of assessing the impact of plant rhizosphere during various stages of growth on the soil microbial community represented in (bacteria, fungi, actinomycetes). Rhizospere is the area extending a few millimeters from the root surface and affect the numbers of micro-organisms in the soil due to biological processes emerging from the roots of plants, it contains many of organic compounds produced from the outputs roots and also contain some of the dead root hairs, which are organic substances and source of carbon and nitrogen in the soil.

Tracking the number of three microbial groups during different stages of growth starting from the stage of seedling until maturity with two types of plant root growth (legumes_Poaceae) The results showed that rhizosphere 'effect depends on the quality of the plant root and the age of the plant. In the bean and barley plants numbers of bacteria and fungi increased from the early stages of plant growth then began to decline during the maturity stage. But in a much higher degree beans from barley. While numbers of actnomycetes increased during the advanced stages of plant life.

Using the of ratio $\mathrm{R} / \mathrm{S}$ to study the effect of the roots on the numbers of the microbes in the soil, it was found that the rhizosphere has a clear impact on increasing the numbers of soil bacteria particularly' compared to fungus numbers with plant growth progress in general, The effect was higher in the bean plant then barley. The numbers of bacteria increased in the rhizosphere from what it was in the soil, reaching 100 million in bean and in barley 200 times while fungi were 1000 times in beans and barley 100 times. For actnomycetes were encouraging influence of the rhizosphere during the advanced stages especially maturity stage reaching to 10,000 times in bean plant and in barley to 1000 times,. Statistical analysis showed that there is a significant effect of the interference between the type of plant and of numbers microbes, any type of plant that affect the of numbers microbes throu various stages of growth at a significance levels of 0.05 and as well 0.01 . 